\title{
Béla Bartók’s Controversy with Géza Molnár in 1911: As a Member of the "Transitional Generation"1
}

\author{
Yoshiko Окамото \\ The University of Tokyo, Japan \\ Komaba 3-8-1, Meguro-ku, Tokyo, 153-8902 Japan \\ E-mail: y.okamoto@komex.c.u-tokyo.ac.jp
}

(Received: April 2015; accepted: January 2017)

\begin{abstract}
Béla Bartók's “On Hungarian Music," one of his controversial articles published in 1911, is known for criticizing Géza Molnár's book, Theory of Hungarian Music (1904). However, it has not been mentioned that Molnár himself replied to Bartók's article in the next volume of Aurora [Dawn] magazine, using exactly the same title as Bartók's. While Bartók asserted that true Hungarian music had never existed before, Molnár, a musicologist in Budapest, bitterly criticized Bartók's assertions from an academic perspective. This controversy over Hungarian music published in Aurora seemed quite crucial for understanding and relativizing Bartók's position at that time. The historian Mary Gluck explained that several intellectuals, including György Lukács and Béla Balázs, had to depend on the older generation, both financially and philosophically, during that period. Using Gluck's framework, this paper examines the genesis of Bartók's article and the connection between him and the intellectuals in 1911, as well as to interpret this controversy. In conclusion, the controversy with Molnár, and plausible "defeat" in the field of musicology could be added to his list of challenges and setbacks before 1912, the year that saw Bartók's temporal exit from public musical life.
\end{abstract}

Keywords: Béla Bartók, Géza Molnár, Aurora, controversy, modernism

1. This paper is a translated and revised version of the second chapter and the appendix of my $\mathrm{PhD}$ dissertation, which was submitted to the University of Tokyo. Yoshiko Okamoto, Shimpigeki wo Operaza e: Barutok to Barazyu no Kyodo Sakuhin toshite no 'Aohige-Ko no Shiro' [Staging the Mystery Play within the Opera House: Bluebeard's Castle as a Collaboration of Bartók and Balázs] (PhD diss., University of Tokyo, March 2014) [written in Japanese]. 


\section{Introduction}

In 1911, Bartók prolifically worked in various fields: playing as a pianist, teaching piano at the Royal Academy of Music, collecting folk music, founding the New Hungarian Music Society (Új Magyar Zene-Egyesület), and editing other composers' piano scores. He also wrote articles and reviews for journals such as Zeneközlöny (Music Journal).

Among Bartók's activities, recent studies focused on "On Hungarian Music," one of his most controversial articles, which was published in the March 1911 issue of Aurora magazine in Budapest. In this work, Bartók allegedly attempted to criticize Géza Molnár's book, Theory of Hungarian Music (A magyar zene elmélete), published in $1904 .^{2}$ Molnár had been a music historian and a professor at the Royal Academy of Music since 1900, ${ }^{3}$ and Bartók annotated his copy with critical comments. ${ }^{4}$

In previous studies about Bartók, Schneider and Ota dealt with the article from the aspect of continuity (and discontinuity) from the nineteenth century. ${ }^{5}$ Hooker also mentioned this text regarding the New Hungarian Music Society's ideas and background. ${ }^{6}$ Bartók's assertions were quite radical and clear - that true Hungarian music had never existed before him, and a Hungarian musicologist (allegedly referring to Molnár) consequently analyzed music that had never existed. According to Bartók, he and his colleagues would produce Hungarian music in the near future.

However, the origin and context of this article has not been examined to its full extent. For example, it has not been mentioned that Molnár himself replied to Bartók's article in the next volume of Aurora, using exactly the same title. Considering that Aurora was not a music magazine but a general art journal, it seemed that Bartók's reason for contributing to it was to reveal his detailed ideas and personal exchanges or relationships with other artists.

Thus, this paper aims to reveal the genesis of the article and interpret this controversy, especially from the perspective of Bartók's relationships with other intellectuals and their influences on him. 1904).

2. Géza Molnár, A magyar zene elmélete [Theory of Hungarian Music] (Budapest: Pesti Könyvnyomda,

3. “M. Géza,” Magyar Zsidó Lexikon [Hungarian Jewish Lexicon], http://mek.oszk.hu/04000/04093/ html/szocikk/13410.htm (accessed March 9, 2015).

4. See an annotation of "On Hungarian Music" in Bartók Béla Irásai [Béla Bartók’s Writings], ed. Tibor Tallián (Budapest: Zeneműkiadó, 1989), vol. 1, 101.

5. David Schneider, Bartók, Hungary and the Renewal of Tradition: Case Studies in the Intersection of Modernity and Nationality (Berkeley: University of California Press, 2006), 12-13 and Mineo Ota, Bartoku no Modanizum to Bunka-Nashonarizum [Cultural Nationalism and Modernism in Béla Bartók's Activities On the Role of "Peasant Music"] (Tokyo: The University of Tokyo, 2010), 61. (In Japanese).

6. Lynn Hooker, "Modernism on the Periphery: Béla Bartók and the New Hungarian Music Society of 1911-1912," Musical Quarterly 88 (2006), 279. 


\section{Aurora, Short-Lived Art Journal in 1911: Bartók's Personal Exchanges with Contemporary Artists}

Aurora was quite short-lived, published from January 31 to August 19, 1911 (the 16-17th issue was possibly the last one) (Plate 1). The editor-in-chief was Andor Cserna (1885-1933), a music critic. Initially, from January to March, Aurora was a monthly journal on "literature, art, drama, [and] music" ("irodalom-müvészetszínház-zene"). However, it soon became a more general-interest, "weekly publication on literature and art" ("irodalmi és müvészeti hetilap") from April to its closing (Plate 2). Compared with music magazines, such as Zeneközlöny, Aurora was an interdisciplinary magazine and included various articles about literature, painting, music, and drama.

Plate 1 Aurora 3 (1911, March 16)

(General Collection of the National Széchényi Library, Budapest)

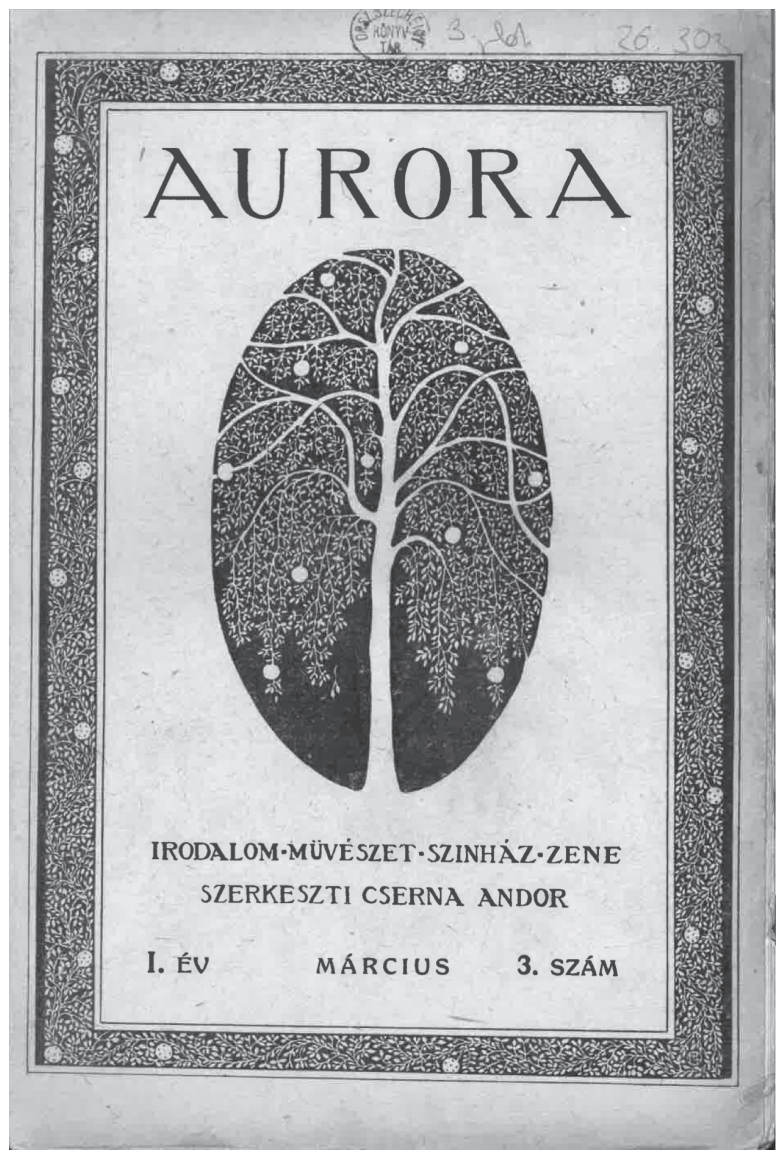


Plate 2 Aurora 4 (1911, April 8)

(General Collection of the National Széchényi Library, Budapest)

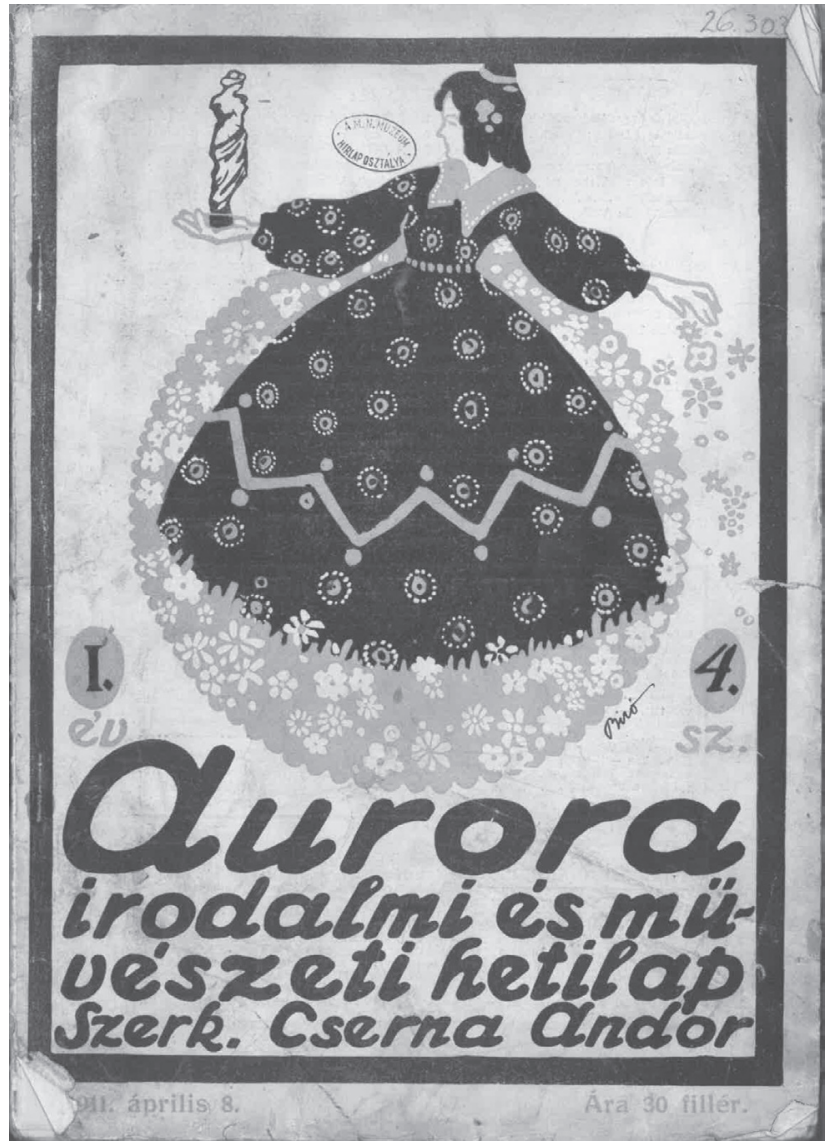

In that period, the literary journal Nyugat (The West) had such a strong influence on young intellectuals that many new magazines were subsequently established, for example, Szellem (Spirit), Szinjáték (Play), Renaissance (all in 1910), and Aurora in 1911. All these magazines were short-lived, but young intellectuals attempted to differentiate each from Nyugat. For instance, Renaissance (Plate 3), "a journal of politics, society, art, and economy" ("politikai, társadalmi, müvészeti és közgazdasági folyóirat”), edited by Árpád Zigány, emphasized the relationship between politics and arts, in contrast to Nyugat, which aimed at art for art's sake. ${ }^{7}$

7. Ernőné Sándor, “'Renaissance’: Egy politikai-társadalomi-művészeti és közgazdasági folyóirat története (1910-1911)" ["Renaissance:" History of a journal of politics, society, art and economics], in Az Egyetemi Könyvtár évkönyvei (Budapest: Egyetemi Könyvtár, 1971), vol. 5, 204. 
Plate 3 Renaissance 2/2 (1911, January 25)

(General Collection of the National Széchényi Library, Budapest)

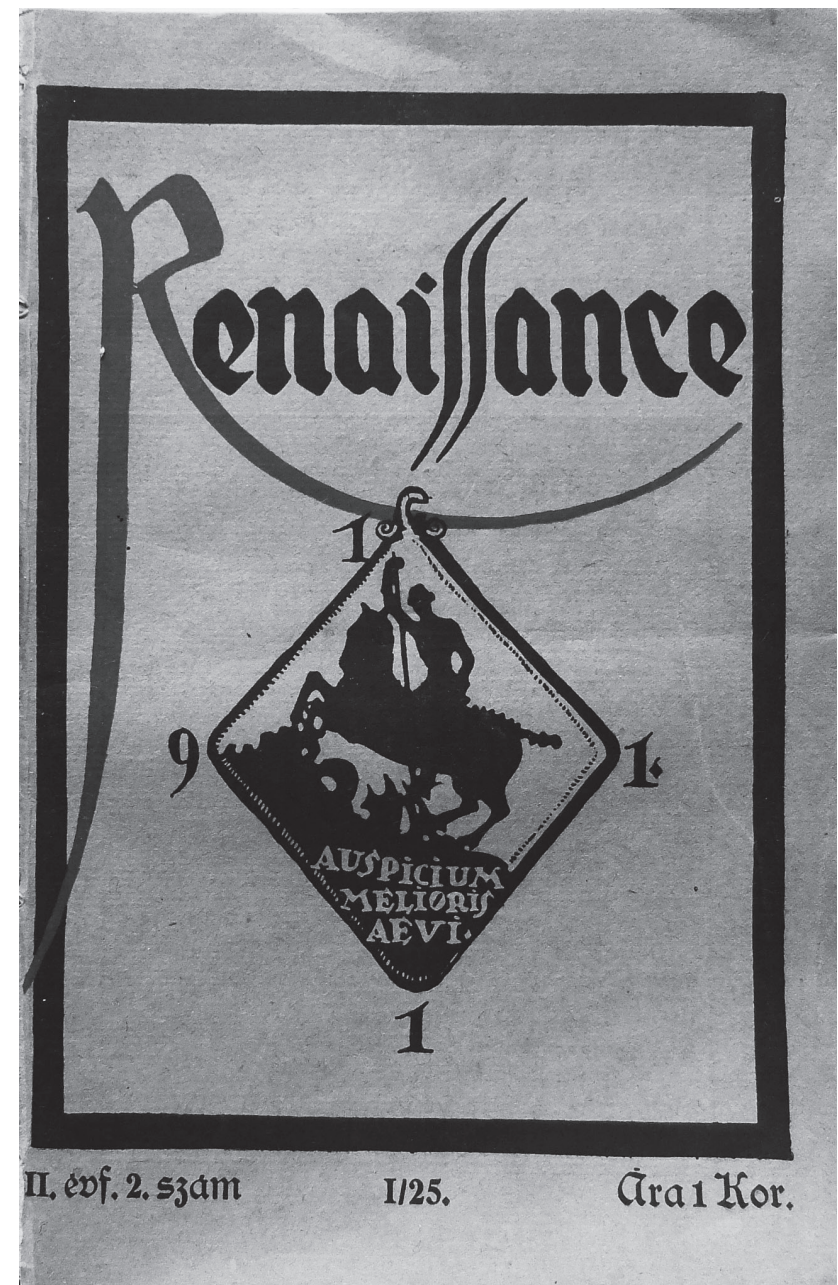

Among the young intellectuals, György Lukács, a philosopher, and Béla Balázs, a poet, playwright, and the librettist of Bluebeard's Castle and Wooden Prince composed by Bartók, were editorial board members of these magazines. Balázs served as an editor of the journals and persuaded other artists, such as Endre Ady and Mihály Babits, to participate in these publications. ${ }^{8}$ He seemed to have recommended Bartók and Kodály as contributors for Aurora, too. Balázs wrote to Lukács: Széchényi Könyvtár, Kézirattár (Manuscript Collection of the Széchényi National Library, Budapest). 
I would just like to tell you that a new journal has been published, which you probably saw: “Aurora.” ... Laczi Bánoczi [László Bánóczi] edits it in secret. I am also very much involved in it. Bartók and Kodály will also contribute to it. ${ }^{9}$

László Bánóczi was one of Lukács' friends who established Thália Society, a theater company in Budapest from 1904 to 1908. Thus, Éva Gábor interpreted Aurora as one of the continuations of "Thália"10, because Bánóczi had planned to publish the society's journal in vain. On the other hand, Ernőné Sándor pointed out that Aurora was a successor of Renaissance since almost the same group of editors and authors started Aurora immediately after Renaissance closed. ${ }^{11}$

Several documents also implied the connections between Bartók and his contemporaries. During that period, Bartók and Balázs were neighbors in the same building on Teréz Ring Street in Budapest. ${ }^{12}$ The editorial office of Színjáték was in that building, too. ${ }^{13}$ In another letter dated February 1910, Balázs wrote Lukács that he had just finished the first draft of Bluebeard's Castle and presumably read it in front of his friends:

Now I am so glad to finish Bluebeard. I also like it except for 5 to 10 mistakes I found. [...] It was almost a huge, huge success (Almost, you know: Edith, Máli [Anna Lesznai], Zoltán, Bartók, Emma Gruber. Huge success, you know: for instance, Zoltán. After listening to it at length with a flushed face, then "Well ..., the writing could still use some improvement)".14

Although Balázs' letters need to be examined more minutely, this letter pointed out Bartók's relationships with artists such as Anna Lesznai and Béla Balázs.

9. “Csak azt akarom írni, hogy van itt egy új lap, melyet talán láttál is azóta, Aurora. ... Titokban Bánóczi Laci szerkesz[t]i. Nekem is teljes befolyásom van rá. Bartók és Kodály is fognak bele írni." Béla Balázs to György Lukács, January 1911, Balázs Béla levelei Lukács Györgyhöz, ed. Júlia Lenkei (MTA Filozófiai Intézet, 1982), 44. Translation is mine. Tibor Tallián also mentions this letter in Bartók Béla írásai, 101.

10. Éva Gábor, ed., A Thália Társaság (1904-1908): Levelek és dokumentumok (Budapest: Magyar Színházi Intézet, MTA Lukács Archívum és Könyvtár, 1988), 26.

11. Sándor, "Renaissance," 220.

12. Yoshiko Okamoto, "Images of the Friendship with Bartók: From Béla Balázs's Recollections," Hungarian Studies 28-2 (2014), 215.

13. For example, contact information of Artúr Bárdos, the editor-in-chief, is written under the table of contents of Színjáték, vol. 1-15: Budapest, VI [district]. Teréz-körút [Teréz Ring Street] 17. Similar to Thália the journal Színjáték also planned several performing productions. See Tamás Gajdó, "Egy Nyugat-matiné története - Balázs Béla: A kékszakállú herceg vára" [An event of Nyugat-matinée - Béla Balázs: Bluebeard's Castle], Színháztudományi Szemle 30-31 (1996), 196-200.

14. "Lelkesített most, hogy befejeztem a Kékszakállút, melyet 5-10 tudott hibájától eltekintve nagyon szeretek. ... Általános nagy nagy sikere volt. (Általános, értsd: Edith, Máli, Zoltán, Bartók, Gruber Emma - Nagy, értsd: pl Zoltánnál- Kipirult arc, hosszú hallgatás, aztán: "Hát ... érdemes volna még jobban megcsinálni”....)". Balázs to Lukács, 21 February 1910, in Lenkei (ed.), Balázs Béla levelei, 5. Translation is mine. 
In that period, Bartók's philosophy changed from the enthusiastic, patriotic style in the 1900s to leftist and cosmopolitan in the 1910s. Bartók's contacts and relationships with Jewish intellectuals influenced him in the background. ${ }^{15}$

Considering the above situations, Bartók's contribution to Aurora was one of his collaborations with other artists or intellectuals. Specifically, his relationship with other young intellectuals enabled him to publish the article (The direct cause of Bartók's attempt to write the article is discussed in Section 4.). Besides, it is also possible that the magazines inspired Bartók to establish the New Hungarian Music Society because a report of the society was published in Aurora as soon as the society was established. ${ }^{16}$

\section{Bartók's Statement and Molnár's Reply: Different Interpretations of Hungarian Music History}

In this section, the detailed controversy is discussed. As previously noted, it has not been mentioned that Molnár himself replied to Bartók's article in the next issue of Aurora. The article "On Hungarian Music" was written to challenge the situation of the arts in 1911. Bartók's ambition and Molnár's academic position would reveal not only a typical conflict between generations but also music's historical perspectives at that time.

\section{3-1. Bartók's Perspective}

According to Bartók, despite several theoretical books about Hungarian music, there had been no Hungarian music at all. The music played in Budapest cafés was for the gentry. It was "not Magyar [Hungarian] but Gypsy-type music" or "not even representative of national music." ${ }^{17}$ Several composers attempted to produce Hungarian art music in vain; it was just a "mixture."

According to the natural order of things practice comes before theory. We see the opposite with Hungarian national music: ... We did not have, hitherto, a valuable and yet distinctive art music, characteristically Hungarian. ... the endeavors of our serious-minded musicians were also sterile, because, while several of them servilely imitated foreign styles, others, for instance Ferenc Erkel,

15. Lynn Hooker, "The Political and Cultural Climate in Hungary at the Turn of the Twentieth Century," in The Cambridge Companion to Bartók, ed. Amanda Bayley (Cambridge: Cambridge University Press, 2001), 21.

16. Hooker, "Modernism in Periphery," 274.

17. Béla Bartók, "On Hungarian Music," in Béla Bartók Essays, ed. Benjamin Suchoff (Lincoln: University of Nebraska Press, 1992), 301. 
tried to solve the task by wedging between musical items of Italian character one or two Gipsy-type tunes or csárdás. The mixture of such heterogeneous elements does not produce a Hungarian style, merely a conglomerate lacking any style. ${ }^{18}$

In these paragraphs, Bartók criticized not only Molnár but also Ferenc Erkel regarding music compositions in Hungary. Erkel was one of the representatives of Hungarian operas in the 19th century. The year 1910 happened to be the 100th anniversary of his birth. According to a 1909 report, from 1884 to 1909, Erkel's operas were produced 254 times, far more frequently than any other Hungarian opera (Karl Goldmark: 171, Jenő Hubay: 93, Géza Zichy: 63, and Ede Poldini: 28). Erkel's productions were the fourth most frequently produced after the non-Hungarian operas (Wagner: 562, Verdi: 510, and Meyerbeer: 290). ${ }^{19}$ This reveals how dominant Erkel's compositions were in the Hungarian Opera House. Moreover, in 1911, a memorial book about Erkel stated that Hungarians strived for new Hungarian opera composers following Erkel. ${ }^{20}$ Given this context, Bartók's article was such an assertive text about the older generation.

In the latter half of the article, Bartók painted a picture of upcoming Hungarian music. According to him, true Hungarian music would only be produced through interactions between contemporary composers and Hungarian folk music.

\begin{abstract}
And that event might come to pass if some composers appeared there - each a vigorous individual in his own right - who endowed their compositions with common features, which do not exist in music born on foreign soil, and which, for this reason, must be declared as general characteristics of the Hungarian art music. It might be that these common features will originate out of the interconnection of the composers leading a common life, or it might happen under the influence of genuine Hungarian folk music. ${ }^{21}$
\end{abstract}

Bartók's statement about Hungarian music was quite similar to that of other modernists, such as Ady or Lukács. ${ }^{22}$ For instance, Lukács wrote about Hungarian drama in Chapter 15 of his book, entitled The History of Development of Modern

18. Ibid., 301.

19. A M. Kir. Operaház Igazgatósága [Board of Directors of Hungarian Royal Opera House], A Magy. Kir. Operaház 1884-1909: adatok a színház huszonötéves történetéhez [Hungarian Royal Opera House 18841909: Data of the Theater History 125 years] (Budapest: Markovits és Garai, 1909).

20. Bertalan Fabó (ed.), Erkel Ferencz emlékkönyv [Memorial Book of Ferenc Erkel] (Budapest: "Pátria" Irodalmi Vállalat, 1910), 239.

21. Bartók, “On Hungarian Music,” 302.

22. As for Ady's influences, see Judit Frigyesi, Béla Bartók and Turn-of-the-Century Budapest (Berkeley: University of California Press, 1998). 
Drama published in $1911 .{ }^{23}$ He stated that critics should treat Hungarian drama differently from those of other countries in the history of modern drama because Hungarian dramas had lacked philosophy. ${ }^{24}$ According to him, although Hungarian drama, such as those written by Menyhért Lengyel or Ferenc Molnár, had enjoyed huge success in foreign countries, its contents were superficial. ${ }^{25}$

However, compared with Bartók, Lukács' attitude toward modern Hungarian art was depressive. On one hand, Lukács gave up on the birth of Hungarian modern drama; eventually his depression drove Balázs to write Hungarian-style drama, Misztérium (Mystery play), which includes Blubeard's Castle. On the other hand, as a composer, Bartók attempted to create true "Hungarian music" by himself.

How, then, did he create true Hungarian music? Although Bartók stated that he could do so with his contemporaries by using Hungarian folk music, at that time, he seemed to lack specific methods or ideas to write about in his article. This text was a declaration of upcoming, as-yet-unknown Hungarian music, addressed to the older generation, such as Molnár.

\section{3-2. Molnár's Refutation}

Molnár immediately answered Bartók in his article with the same title in the next issue of Aurora (Plate 2). ${ }^{26}$ Molnár did not mention Bartók's name but considering its title and content, Molnár obviously wrote the article in reply to Bartók. He explained that his purpose was just to promote the characteristics of Hungarian music.

My method was the same as the method adopted by national prosodies. Prosody establishes especially, for instance, what kind of genres, what kind of structures of strophes and what kind of metrical lines, and what kind of cadences and rhyming modes emerge in the national literature. This book would not like to train poets but would like to spread knowledge about poetry. This enlargement has been the purpose of theorists, who were involved in the theory of Hungarian music. ${ }^{27}$

Using a literary analogy, Molnár asserted that people could depict Hungarian music in general. Besides, not only in Hungary but also in foreign countries, many theories had been developed before representative composers, such as "Palestri-

23. György Lukács, A modern dráma fejlödésének története (Budapest: 1911, Reprint, Budapest: Magvető Kiadó, 1978), 581.

24. Ibid., 581-582.

25. Ibid., 597-599.

26. Géza Molnár, "Magyar Zenéröl” [On Hungarian Music], Aurora 4 (1911, April 8), 14-16. For the original text, see the appendix.

27. Ibid., 14. Translation is mine. 
na, Handel, or Bach," created important compositions. Moreover, several foreign composers even praised Hungarian compositions, for example, of Mosonyi.

Then he proceeded to criticize Bartók's opinion. According to Molnár, Hungarian music existed because there had been many Hungarian composers or theorists such as "Liszt, Erkel, Doppler, Huber, Thern, Mosonyi, Mihalovich, Hubay, Szendy, Szabados, and Buttykay" or Ábrányi. It was "true" folk music that Bartók insisted comprised the songs "the train has brought," and everyone knew the difference between Hungarian, Slovak, Romanian and "Gypsy" music. Moreover, there was a lot of Hungarian folk music before Christ's time, and some of it had already disappeared:

I heard that they were "finally able to discover" several true Hungarian songs.

Dear readers, this is a very important point. This true, ancient Hungarian song has just been loaded. Just now the train has brought it. ... Even the pagan Hungarians already had a folk music. However, the relics of the folk music have only been found since 1500 . The older relics had already disappeared, but many songs existed even in 1500 which are not available today. Therefore, we are able to establish the theory of Hungarian music not only in 1900 but also in $1800,1700,1600$, [and] even before it. This is my academic belief. ${ }^{28}$

Molnár's refutation was even more bitter and ironic than Bartók's assertion. However, this academic polemic directly targeted the problem of Hungarian music. Molnár stated that it was modernization that brought Bartók's achievement of "discovering" Hungarian music (probably the phonograph, a recording device, could be added to the railway train). He also remarked that the antiquity of folk music that Bartók insisted was not absolute; it was because folk music was actually Hungarian music in 1911.

A counter response from Bartók has not been found. This was presumably the first academic controversy that Bartók experienced.

\section{3-3. What Prompted Bartók Write "On Hungarian Music" at All?}

The next question is why Bartók wrote the article and started the controversy. My hypothesis is that Bartók's article itself was a reply to Molnár's review of a concert in which Bartók's Two Portraits and Romanian Dances were premiered on February 12,1911 . The texts give several clues. The latter part of the article includes some composers' names and quotations.

28. Ibid., 16. 
Those who have a faulty ear will call such influence as being of the Strauss, Reger, or Debussy type, for they will not be able to sense the subtle nuances. ... Anything unfamiliar is equally "obnoxious". I even dare to say that the oddity built on the customary major-minor scales and chromatic motion of the West Europeans is closer to the Hungarian "critic" than the Asian "frightfulness" of a simple ancient Székely melody. ${ }^{29}$

The keywords are "Strauss, Reger, or Debussy" and three quotations: "obnoxious" "critic," and "frightfulness." First, regarding the names of composers, the leading literary magazine Nyugat also published a review of the concert in its March 16, 1911 issue. Nyugat had previously made quite favorable remarks about Bartók, and the reviewer, Dezső Jász, praised Bartók's new compositions in the article. The review added, "In Portrait, unprejudiced critics could not have shown any reminiscences of Strauss, Reger or Debussy." ${ }^{30}$ In parallel with Bartók's text, it is plausible that one of the critics criticized that Portrait sounded like "Strauss, Reger, or Debussy."

The other clues are the three quoted words. As Ito mentions, above, Bartók often cited the same words that his opponent in a debate had used in order to ironically criticize the other side. (For example, remember the controversy in 1936. Bartók seemed to cite deliberately the word "cultural superiority" from Elemér Sereghy's critic in the controversy ${ }^{31}$ ). In my view, Bartók consciously cited the words "obnoxious," "critic," and "frightfulnesss" to criticize the "Hungarian critic."

Reference can be made to various reviews of this concert in Demény's study; according to this, Molnár's review had not been discovered. ${ }^{32}$ However, from the points mentioned before, Molnár might have published a review in a magazine or given a lecture after the concert, where he criticized that Portrait had a reminiscence of "Strauss, Reger, or Debussy."

29. Bartók, "On Hungarian Music," 302.

30. Dezső Jász, "Bartók új munkái,” [Bartók’s New Works] Nyugat 6 (1911, March 16), [without page number] http://epa.oszk.hu/00000/00022/00076/02327.htm (accessed April 4, 2015).

“"Portrait'-jában az elfogulatlan bíráló nem mutathat ki nyomokban sem semmiféle Strauss, Reger vagy Debussy reminiszcenciát."

31. Nobuhiro Ito, Barutoku: Minyo wo "Hakken" shita Henkyo no Sakkyokuka [Bartók: A Composer in Periphery "Discovering” Folk Songs] (Tokyo: Chuokoron-Shinsha, 1996), 91. [Written in Japanese].

32. János Demény, "Das Konzert vom 12. Februar 1911," in Documenta Bartókiana, ed. Denijs Dille (Mainz: Schott, 1965), vol. 2, 77-90. 


\section{Conclusion: Bartók's Contacts with the "Transitional Generation" in 1911}

In his article, Bartók attempted to criticize the older generations of Hungarian composers, such as Erkel or Liszt. He also tried to question the assumption that Gypsy music was Hungarian music. It is important to note that Bartók participated in the public discussion or controversy not only in musical reviews such as Ethnographia (a journal in which Bartók first published reports of the fieldwork of folk music) and Zeneközlöny. After this controversy, it was in 1913 when he contributed to Nyugat and re-started to state his opinions in public discussion in a general art journal.

As noted in Section 2, Bartók had contacts with Balázs and Lesznai and they would eventually become members of the Sunday Circle group. In her book entitled Georg Lukács and his Generation: 1900-1918, Mary Gluck called Lukács and his friends (Balázs and Lesznai) "part of an essentially transitional generation, uneasily bestriding two epochs, fully at home in neither but intuitively understanding both," and they "had been more dependent on the despised liberal order they hoped to transcend than they could possibly have realized in the years before the war." 33 They were between two generations: one was the older, liberalistic, rationalistic, and idealistic generation of the nineteenth century; the other was the younger, radicalistic, and uncompromised avant-garde generation, such as that of Lajos Kassák or László Moholy-Nagy. Although as modernists, they dismissed the former generation, they had to depend on it philosophically and financially. They dwelt on creating "Hungarian" art and benefitted from Lukács' father's sponsorship of their activities such as Thália Society or the journal Szellem. Moreover, they still slightly lacked a specific method of how to create truly and purely Hungarian art though they challenged the older generation.

As for Bartók's activities, including his article "On Hungarian Music," he was also in the similar predicament although he never stuck to one idea in his life. Lynn Hooker pointed out that the motivation of the New Hungarian Society was not only a shared ideal but also dissatisfaction with the then Hungarian concerts and musical life in Budapest. ${ }^{34}$ At least in 1911, Bartók was physically and philosophically close to young intellectuals such as Balázs, and audaciously challenged the older generation. However, Bartók's position in that period reflected an ambivalent stance, considering that he taught in the Royal Academy, and his Bluebeard's Castle, produced in collaboration with other artists, was submitted to a Hungarian

33. Mary Gluck, Georg Lukács and his Generation 1900-1918 (Cambridge, MA: Harvard University Press, 1991), 221.

34. Hooker, "Modernism on the Periphery," 275. 
opera competition as a memorial of Erkel's 100th birthday. ${ }^{35}$ Moreover, as discussed, the folk music discovered by Bartók was also one of the results of modernization. In this sense, Bartók belonged to the transitional generation in 1911.

This study has dealt with the discussion between Bartók and Molnár and interpreted this controversy from the aspects of generation and the influence of the intellectuals close to Bartók. Bartók's inconsistent attitude calls for further discussion on how his philosophy changed. In her 2000 paper, Judit Frigyesi discussed the similarity between Bartók's Bluebeard's Castle and Lukács' philosophy or Ady's poetry. In questioning this similarity, she attempted to describe this cultural context academically because pointing out the similarity would explain almost nothing. ${ }^{36}$ Consequently, she aimed "to experiment with an alternate scholarly discourse that stretch the limits of scholarship toward ambiguity for the sake of a better reflection of reality, but without giving up the option of arguing a point" to discuss the ambiguous context. ${ }^{37}$ On the other hand, the controversy and genesis of the article in Aurora imply the plausibility of revealing the relationship between Bartók and his contemporaries by using their documents and resources. Consequently, it also clears some ambiguities, especially regarding stage works such as Bluebeard's Castle and Wooden Prince, which include literary works, or critics, in which authors express their opinions directly.

\section{Appendix: Géza Molnár, “On Hungarian Music” (1911)}

\section{Original Text}

Azokat az előadásokat, amelyeket a magyar zene sajátságairól tartok, rendszerint a következő szavakkal nyitom meg:

"Ne gondolják önök egy percig sem, hogy itt törvényeket, szabályokat fogunk felállítani. Ne gondolják, hogy önök akár tőlem, akár mástól utasításokat kaphatnának arra nézve, miként kell magyaros irányban dolgozni. Ilyent feltételezni is képtelenség. Mi nem fogunk egyebet csinálni, mint együtt átnézni azt a magyar müzenei és népzenei anyagot, amely 1500 óta rendelkezésünkre áll és meg fogjuk beszélni, mily sajátságok jutnak ezekben a nemzeti dokumentumokban kifejezésre.”

Az én könyvem, amely 1904-ben jelent meg, ezzel a tárgykörrel foglalkozik. Módszere ugyanaz, amelyet már régesrég minden nemzet verstana követ. A poéti-

35. For the competition, see Carl S. Leafstedt, Inside Bluebeard's Castle: Music and Drama in Béla Bartók's Opera (New York: Oxford University Press, 1999), 143-153 and László Vikárius, "Commentary to Béla Bartók Duke Bluebeard's Castle, Opus 11: Facsimile of the Autograph Draft," in Duke Bluebeard's Castle, Opus 11: Facsimile of the Autograph Draft, ed. László Vikárius (Budapest: Balassi Kiadó, 2006), 38-44.

36. Judit Frigyesi, "In Search of Meaning in Context: Bartók's Duke Bluebeard's Castle," Current Musicology 70 (Fall 2000), 20-21.

37. Ibid., 24. 
ka megállapítja többek közt, hogy a nemzeti irodalomban milyen müfajok, milyen strófikus szerkezetek, milyen alkatú sorok, milyen lejtések, rímelési módok stb. jelentkeznek. Nem poétát akar nevelni, hanem ismereteket terjeszteni. Ez volt a célja azoknak is, akik a magyar zene elméletén gondolkoztak. Kezdte 1862-63ban Szénfi Gusztáv, folytatta Ponori Thewrewk, önálló kötetben Ábrányi Kornél, és folytattam én. Aki ezeket a dolgozatokat nyugodt, elfogulatlan szemmel nézi, szándékukat nem fogja elforgathatni.

De egyszerre csak megüti a fülünket egy hang. És ez a hang így szól: „Magyar zene nem volt, hanem lesz! Tulajdonképp nem lesz, hanem most kezdődik éppen. Csak tessék gondosan idefigyelni. Már csináljuk néhányan...!"

Akik pedig teoretizáltunk idáig a magyar zenén, dobjuk tủzbe minden írásunkat, mert mi szegények csak Liszt, Erkel, Doppler, Huber, Thern, Mosonyi, Mihalovich, Hubay, Szendy, Szabados, Buttykay műveit ismerhettük, tehát nem feküdt előttünk komolyan számbavehető anyag. Olyan anyag, amelyből elméleteket lehet konstruálni. Megvallom, én teljes tisztelettel adóztam idáig ezeknek a müvészeknek, sőt Wagner is, aki Mosonyi zongoratanulmányait Bach prelúdiumaival hasonlítja össze, hízelgőbben nyilatkozott ennek a kornak a magyar zenéjéről, mint legutóbb Debussy egyik-másik aktuális kísérletünkről.

Most egyszerre azt kell hinnem, hogy azok a zeneszerzők, akiknek neveit fölsoroltam, mit sem sejtettek a magyar zenéröl. Talán nem is éltek soha magyar földön, a fülükhöz bizonyára nem jutott el soha egy valódi magyar ritmus! Süketek és értelmetlenek voltak. A müveikből nem lehet következtetéseket vonni.

Hogy jár el a külföldi tudomány? Nyomozva valamely nép zenéjének faji elemeit, olyan anyaggal dolgozik, amely távolról sem éri el a Lavotta színvonalát. Egészen primitív - a koránál sokkal régibb - okmányok alapján utal Kircher már 1650-ben (Musurgia universalis) azokra az elemekre, amelyek a német zenét elválasztják a franciától, Cerone már 1613-ban jellemzi (Melopeo stb.) az olasz fajiságot úgy, amennyire 1500-ig kialakult a zenében, Wooldrigde kizárólag 1400 előtti emlékekből hámoz ki egy különleges angol stílust. És íme Palestrina, Bach és Händel nem sértődtek meg, hogy az elemzés nem várta meg azt az időpontot, amire ők megszületnek. A mi zeneszerzőink között egyik-másik sokkal érzékenyebb.

Én azt a véleményt merném kockáztatni, hogy egy nemzet művészetében minden fejlődhetik: formák kiszélesülhetnek, a gondolat elmélyedhet, az érzés fölforrhat, a technika kifinomulhat. A fajiság azonban ősvonás. Vagy megvan benne vagy nincs. Egy müszakilag fejlettebb korszakban nem hitelesebb, mint annakelőtte. A mi régi katona-nótáinkban épp úgy benn lüktet, mint a müvelt Arany Jánosban. Ez nem erudíció kérdése. És én a homofonságban megrekedt Lavottát annak a fölismerésére, hogy ez magyar levegő, magyar hangulat, magyar metrum, tartom oly illetékesnek, mint bármelyik élő magyar zeneszerzőt. Hogy ennek a nemzetnek, amely több mint ezer éve él magyar földön, csak most akad majd néhány zeneszerzője, akinek összmúködéséből ki fog alakulni a fajiságunk - ennél 
naivabb nyilatkozat még nem csúszott ki emberi ajkon. Hogy a jövő hozhat nekünk költőibb, szellemesebb, melegebb zenét, hogy a fajiságunk beolvadhat egy a mainál mesteribb nyelvezetbe, mindezt értem. Mint ahogy el tudok képzelni egy olyan magyar embert, aki okosabb, ravaszabb, élesebb látású minden eddigi magyarnál. De azt nem hihetem, hogy eljövend valaki, aki még hitelesebben fogja képviselni a magyar jellemet, mint Pázmány Péter, Bocskay vagy Deák és azt sem, hogy évszázadokon át elkerülték a figyelmünket a magyar népjellemnek az igazi alkatelemei. Ilyen tréfát nem üznék sem magammal, sem az olvasómmal.

Nem ismerjük - úgy hallom - a tulajdon zenei jellemünket. Íme a megokolás: az eddigi müzenéből, amely silány, nem világlik ki semmi. De a népzenéből sem. Mert ezt ebben az országban senki sem ismeri, - kivéve egy-két embert. A többi csak kávéházba jár és összezavarja a magyar zenét a cigányzenével és a tót zenével. Hálásak vagyunk azért a fölfedezésért, hogy a cigány nem muzsikál mindig szavahihetően. Kár, hogy ezt már minden veréb csiripeli. A könyvemben egész csomó példa illusztrálja a különbséget magyar, tót, oláh és cigány zene között. Riemann is írja már sok évvel ezelőtt: „Die Musik der Ungarn ist nicht zum kleinsten Teil identisch mit der der Zigeuner." És ő is elég könnyelmü ahhoz, hogy részletesen formulázza a magyar zene sajátságait. Ő sem várta be a magyar zene „,ver sacrum”-át. Enélkül pedig nem lehet tudományt csinálni...

Öt is, mást is megtévesztettek az eddigi népdal-gyüjtemények. Mert - azt hallom - mindenki rosszul gyüjtött. Pálóczi Horváth, Ruzitska, Mátrai, Bartalus, Káldy, Kún és a többi magyar gyüjtő. A 16. századbeli magyar táncok, amelyeket kiadtam, azután a katolikus és protestáns eredeti népénekek, az egész kuruckor zenéje, a török háborúk, a hétéves háború, a szabadságharc dalai: egytől egyig hamisítványok, nem színmagyar termékek, elméleti tárgyalásra alkalmatlanok, szóra nem érdemesek. Aki hitt bennük, rosszul járt. Becsapódott Schubert, Volkmann és Brahms is, akik rosszul hallották azt, amit magyar tematikának hallottak és becsapódott tízmillió magyar ember, aki eddig abban a hitben élt, hogy tudja mi a magyar.

Csak most sikerült fölfedezni - úgy hallom - egy pár hamisítatlan magyar dalt. Ezen van, igen tisztelt olvasó, a hangsúly. A mostani szállítmány az igazi, az ösmagyar. Most hozták, most érkezett vasúton.

Szívesen venném, ha valaki a legújabb magyar zenemüvekben mutatna nekem csak egyetlenegy ütemet is, amelyet a szerző magyarnak érez és melynek a speciális magyar íze új elemekből táplálkoznék. Olyanokból, amelyeket eddig nem ismertünk föl mint magyar zenei sajátságokat!

A pogány magyarságnak már volt népzenéje. Emlékeink csak körülbelül 1500 óta vannak. A régibbek elkallódtak, de 1500-ban még megvolt sok olyan dallam, amely azóta elveszett. A magyar zene elméletét tehát meg lehetett volna írni nemcsak 1900-ban, hanem már 1800-ban, 1700-ban, 1600-ban és még ennél is korábban. Ez a tudományos meggyőződésem. Mint magánembernek persze nem 
lehet kifogásom az ellen sem, ha valaki azt írja, hogy a magyar zene története vele kezdődik. Ha többször tollat ragad, - gondolja - még megjöhetnek a hívők. Tehát csak tessék folytatni ezt a szerencsejátékot. Messieurs, faites vos jeux.

\section{English Translation ${ }^{38}$}

I usually open my speech about the characteristics of Hungarian music with the following words:

"Please, never expect that here we will be able to define rules or regulations. Please, never expect that you could get instructions from someone or me on how to proceed in the Hungarian direction. Such an assumption is impossible. We will not do anything like looking over Hungarian art music and folk music at the same time, which has existed since 1500 . We will talk about characteristics that appear in national music resources."

My book, which was published in 1904, dealt with this theme. My method was the same as the method adopted by national prosodies. Prosody establishes especially, for instance, what kind of genres, what kind of structures of strophes and what kind of metrical lines, [and] what kind of cadences and rhyming modes emerge in the national literature. This book would not like to train poets but would like to spread knowledge about poetry. This enlargement has been the purpose of theorists, who were involved in [the] theory of Hungarian music. Gusztáv Szénfi started [the theory] in 1862-63, Ponori Thewrewk continued it, Kornél Ábrányi also continued it in a separate book, and I followed. People who read these papers calmly and objectively will not distort the theorists' intentions.

However, suddenly, someone whispers words in our ears. [The person] says, "Hungarian music has never existed before and is coming now! Precisely speaking, it is not to come but it is being born just now. Please pay attention that we are already cultivating [Hungarian music]...!"

So then, why do not we, Hungarian theorists, throw away all our books? It is because we miserable people knew only [the] compositions of Liszt, Erkel, Doppler, Huber, Thern, Mosonyi, Mihalovich, Hubay, Szendy, Szabados, and Buttykay so that there have been no serious and considerable resources in front of us, resources from which we would be able to establish music theory. I confess that I have treated these artists with high respect. Moreover, Wagner, who compared Mosonyi's piano études with Bach's preludes, praised the Hungarian music of that period with more respect. Similarly, Debussy recently praised our experiments with Hungarian music.

I also have to consider that the composers mentioned above must not have thought about Hungarian music at all. Probably, they had never set foot on Hun-

38. Translation is mine. 
garian soil and never heard real Hungarian rhythms! They were deaf and idiots. It is impossible to draw consequences from their compositions.

How is foreign scholarship developing? When they traced the ethnic characteristics of music, they dealt with resources that fell below the standards of Lavotta. Even in the 1650s, Kircher (Musurgia universalis) had already mentioned the elements that differentiated German music from French one, using completely primitive - even more ancient than that period - sources. Cerone already pointed out the characteristics of Italian music in 1613 (Melopeo, etc.). These characteristics were shaped before 1500 . Wooldrigde revealed the English style of music by using relics from before 1400. Palestrina, Bach, and Händel were not annoyed about the fact that the theories did not wait until they were born. Some of our composers seem to be far more sensitive.

I dare to say my opinion: in a national art, everything can develop. Forms can enlarge, philosophy can deepen, feeling can rush, and technology can get sophisticated. However, ethnic characteristics are ancient, whether something exists or not in them. It is no more authentic now than it was in the past, before the period when the technology advanced. It pulsates as much in our old martial songs as in the songs of the erudite poet János Arany. This is not a question of erudition. I consider Lavotta as brilliant as every still-living Hungarian composer. Lavotta stuck to what he considered the Hungarian feeling, Hungarian atmosphere, or Hungarian rhythm in homophony. No human being has ever stated such an optimistic manifestation that true composers [have] finally [been] born in the Hungarian field, even if the ethnic group had lived over 1000 years, and the national characteristics are emerging from their collaboration. I understand that the future will provide us with more poetic, more sophisticated, passionate music and that our national characteristics mix with other skilled idioms. Similarly, I could also expect upcoming Hungarian people who are cleverer, smart, and have broader perspectives than before. However, I do not think that someone is coming who represents Hungarian characteristics more authentically than Péter Pázmány, Bocskay, or Deák. Neither do I think that we could have not noticed Hungarian national characteristics and true essence for centuries. Such a joke would not please any readers or me.

I have heard that we do not know about actual musical characteristics. The reason is as follows. The past art music compositions were poor, and they revealed nothing. However, it is not the case with folk music. In this country, no one knows this folk music - except for one or two composers. Others just go to coffee houses and regard Gypsy music and Slovak music as Hungarian music. What a precious discovery is the idea that Gypsies do not always authentically play music. It is only a shame that everyone knows that. My books show the differences between Hungarian, Slovak, Romanian, and Gypsy music. Riemann also wrote many years ago: "Die Musik der Ungarn ist nicht zum kleinsten Teil identisch mit der der 
Zigeuner [Hungarian music is not the same as Gypsy music in even a tiny part]." He did not pay any careful attention to the stylization of Hungarian music. He did not wait for the "sacred spring" of Hungarian music, without which we cannot do scholarship...

Other folk music collections misled him and others. I heard that it was because everyone collected folk music the wrong way. They were Pálóczi Horváth, Ruzitska, Mátrai, Bartalus, Káldy, Kún, and other collectors. The sixteenth-century Hungarian dances that I published, Catholic or Protestant, original folk music, and nationalist music under the Rákóczi era, and the songs during the wars with Turkey, Seven Years' War, and war of liberation were all artificial, were not genuine Hungarian songs, and were not suitable for theoretical discussion because they had no value. Those who believed had to suffer from such a disaster. Schubert, Volkmann, and Brahms incorrectly listened to music that was considered Hungarian in theme. This music lied to them, as well as to ten million Hungarians, those people who had believed that it was Hungarian music.

I heard that they were "finally able to discover" several true Hungarian songs. Dear readers, this is a very important point. This true, ancient Hungarian song has just been loaded. Just now the train has brought it. I would love to buy one if someone [would] quote even one passage from which [a] composer [could] feel Hungarian characteristics and enjoy the special Hungarian taste of the new elements - the elements that we had never considered Hungarian music at all!

Even the pagan Hungarians already had a folk music. However, the relics of the folk music have only been found since 1500 . The older relics had already disappeared, but many songs existed even in 1500 which are not available today. Therefore, we are able to establish the theory of Hungarian music not only in 1900 but also in 1800, 1700, [and] 1600. This is my academic belief. Of course, as a private man, I would not refute one's idea that he started the history of Hungarian music. However, believers often gather around a man who repeatedly puts pen to paper. Until then, continue gambling. Messieurs, faites vos jeux [Gentlemen, place your bets]. 